\title{
ANTYNESTORIAŃSKA TEOLOGIA WCIELENIA CYRYLA ALEKSANDRYJSKIEGO
}

1. Kontekst doktrynalny. Naukę Cyryla o wcieleniu niepodobna przedstawić i rzeczowo omówić, w oderwaniu od jej genezy, zakotwiczonej w dyskusjach chrystologicznych, poprzedzających kryzys nestoriański. Nasilający się po Soborze Nicejskim arianizm, kwestionował zarówno prawdziwe bóstwo Chrystusa jak i pełnię Jego człowieczeństwa. Według Ariusza Chrystus nie posiadał duszy ludzkiej, ponieważ jej miejsce zajął stworzony Logos ${ }^{1}$. Apolinary z Laodycei, przyjmując platoński podział duszy na zmysłową (psyche) i rozumną (nous), twierdził, że Chrystus nie posiadał pełnej duszy ludzkiej: „W Chrystusie miejsce ludzkiego nous zajęło boskie Logos, które dokonało w nim zjednoczenia i stało się przyczyną wszelkiego działania"2.

Wysiłki teologów ortodoksyjnych zmierzały w dwóch kierunkach: z jednej strony akcentowano, że Chrystus posiada pełnię bóstwa i pełnię człowieczeństwa, $\mathrm{z}$ drugiej podejmowano próby określenia w jaki sposób bóstwo i człowieczeństwo łączyły się w Chrystusie. W tej ostatniej kwestii wyodrębniły się dwa stanowiska. „Grupa teologów i biskupów, zwana szkołą antiocheńską, mimo dużego zróżnicowania, nie tylko przyjmowała pełne Bóstwo w Chrystusie, ale także i pełne człowieczeństwo, co wyrażało się w schemacie «Logos - Anthropos» (,Słowo - Człowiek”). Szkoła ta kładła nacisk na dwie natury w Chrystusie, często widząc je jako w zwykły sposób zmieszane ze sobą (np. Kapadocjanie). Przy tym uważano, że zbawienie przychodzi przez naturę ludzką, o ile jest ona narzędziem w ręku natury Boskiej.

Szkoła aleksandryjska [...] rozwijała chrystologię według schematu «Logos - Sarks» („Słowo - Ciało”), a więc Logos zjednoczył się z ciałem ludzkim. Nie było dostatecznie jasne, czy Ciało oznaczało całego człowieka, czy też było ono bez duszy, której rolę przejęło we wszystkim Słowo (apolinaryzm). W każdym razie podkreślano jedność natury w Chrystusie i pochodzenie zbawienia od

\footnotetext{
${ }^{1}$ Por. F. Drączkowski, Patrologia, Pelplin-Lublin 1998, s. 188; H. Pietras, Początki teologii Kościoła, Kraków 2000, s. 211.

2 Por. J. M. Szymusiak, Apolinaryzm, EK I 733.
} 
Bóstwa"3. Do najwybitniejszych przedstawicieli tej szkoły należał Cyryl Aleksandryjski, biskup Aleksandrii w latach 412-444. Linię doktrynalną natomiast szkoły antiocheńskiej reprezentuje Nestoriusz, mianowany w 428 roku biskupem Konstantynopola. Imiona obu tych biskupów związane są z drugą wielką kontrowersją chrystologiczną, która doprowadziła do zwołania soboru powszechnego w Efezie w 431 roku.

W nauce Cyryla o wcieleniu, daje się zauważyć dość znaczne różnice między tezami eksponowanymi przed kontrowersją nestoriańską, czyli przed rokiem 429, a sformułowaniami preferowanymi w okresie późniejszym. W swych pismach antyariańskich (Thesaurus, Dialogi), napisanych przed 429 rokiem, wierny jest nauce Atanazego Wielkiego, który naukę o wcieleniu ujmował w schemacie Logos - Sarks. Przyjmuje fundamentalne sformułowanie chrystologii atanazjańskiej: „Logos nie zstąpił na człowieka, lecz stał się człowie-

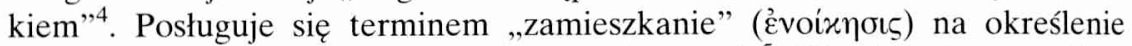
relacji między Bogiem i człowiekiem w Chrystusie ${ }^{5}$. W dziełach powstałych w czasie kontrowersji nestoriańskiej, jego nauka o wcieleniu uległa znacznej modyfikacji, głównie w zakresie używanej terminologii.

2. Logos stał się człowiekiem. W drugim liście do Nestoriusza Cyryl zwięźle określił swoją naukę o Wcieleniu:

„A zatem święty i wielki Synod powiedział, że Ten, który z Boga Ojca według natury się narodził, jest Synem Jednorodzonym, Bogiem prawdziwym z Boga prawdziwego, Światłem ze Światłości, przez którego Ojciec wszystko uczynił; On to przyszedł do nas, przyjął ciało, stał się człowiekiem, został umęczony i zmartwychwstał dnia trzeciego i wstąpił do nieba. Tych słów i tych nauk winniśmy się trzymać, rozważając, co mogłoby znaczyć, że Słowo Boże wcieliło się i stało się człowiekiem. Nie mówimy bowiem, że przekształcona natura Słowa stała się ciałem ani też nie twierdzimy, że natura Słowa zamieniła się w całego człowieka, złożonego z duszy i ciała, lecz utrzymujemy, iż Słowo jednocząc się substancjalnie $z$ ciałem ożywionym i duszą rozumną stało się człowiekiem w sposób niewypowiedziany i niepojęty oraz nazwane zostało Synem człowieczym; nie tylko z samej woli czy upodobania ani też nie przez samo przyjęcie tylko osoby, lecz z tej racji, że z obu różnych natur, które połączyły się w prawdziwym związku jedności, powstał jeden Chrystus i Syn. Zjednoczenie to, polegające nie na uszczupleniu różności natur, lecz na tajemnym i cudownym zespoleniu w jedno Bóstwa i czlowieczeństwa, dało nam jednego Syna, Chrystusa i Pana" .

${ }^{3}$ Cz. Bartnik, Sobór Efesko-Aleksandryjski jako wydarzenie historyczne, w: Maryja w tajemnicy Chrystusa, praca zbiorowa pod red. S. C. Napiórkowskiego - S. Longosza, Niepokalanów 1997, s. 30.

${ }^{4}$ Dialogus I, PG 75, 659-712; por. Athanasius, Contra arianos III 30, PG 26, 388A.

5 Por. Thesaurus 23, 24, 28; Dialogus V.

${ }^{6}$ Epistula 4, PG 77, 45B-C, thum. F. Drączkowski, w: Maryja w tajemnicy Chrystusa, praca zbiorowa pod red. S. C. Napiórkowskiego - S. Longosza, Niepokalanów 1997, s. 232. 
W powyższej wypowiedzi Cyryl wykłada naukę o „zjednoczeniu hipostatycz-

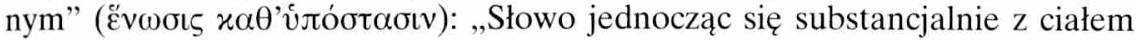
ożywionym i duszą rozumną stało się człowiekiem". To zjednoczenie polega „na tajemnym i cudownym zespoleniu w jedno Bóstwa i człowieczeństwa”. Owa ع̋vwoıs nie oznacza pomieszania obu natur; jest to zjednoczenie bez

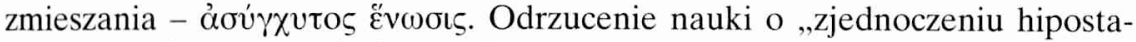

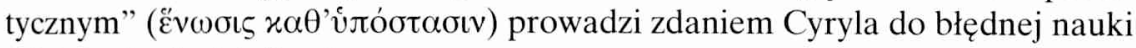
o istnieniu dwóch Synów:

„Jeśli zaś nie chcemy przyjąć zjednoczenia istotowego, z tej racji, że jest niemożliwe albo niestosowne, to w konsekwencji musimy uznać, że istnieją dwaj Synowie" .

Zwalczając błędy nestoriańskie Cyryl odrzuca wszystkie te określenia, które niedostatecznie precyzują wewnętrzny oraz istotowy charakter zespolenia obu natur w jednej osobie Logosu. Nestoriusz w liście do Cyryla stwierdza: „Pięknie zatem i zgodnie z przekazem Ewangelii wyznajemy, że ciało Syna było świątynią dla Jego Bóstwa" 8 . Takie określenie sugeruje, że zjednoczenie Bóstwa i człowieczeństwa było czysto zewnętrzne. Stąd Cyryl odrzuca określenia

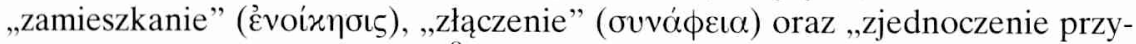

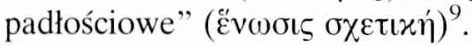

Cyryl zdecydowanie podkreśla jedność podmiotu zjednoczenia, w sensie, jedna jest tylko hipostaza, czyli osoba Logosu ${ }^{10}$. Unika określenia, że „Chrystus przyjął naturę ludzką". W liście do Nestoriusza, nawiązuje do Janowej

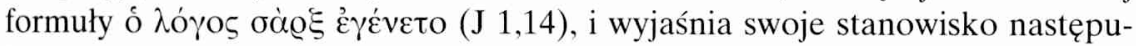
jąco:

„Pismo Święte przecież nie mówi, że Słowo połączyło się z osobą ludzką, lecz że

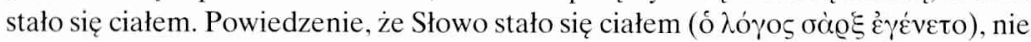
oznacza nic innego, jak to, że Słowo podobnie jak my uczestniczyło w ciele i krwi, że ciało nasze uczyniło swoim, że przyszło na świat jako człowiek narodzony $\mathrm{z}$ niewiasty, nie porzucając swego bytowania Bożego ani swego zrodzenia z Boga Ojca, lecz biorąc ciało pozostało takim, jakim było przedtem"11.

3. Zjednoczenie bez uszczuplenia różności natur. W Liście do Nestoriusza

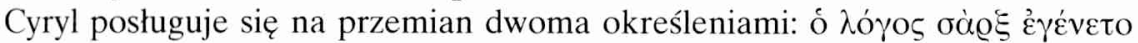



7 Tamże, PG 77, 48C, Drączkowski s. 233.

${ }^{8}$ Epistula 5 (Nestorii ad Cyrillum), 7, PG 77, 56A, tłum. F. Drączkowski, w: Maryja w tajemnicy Chrystusa, s. 229. Wszystkie dalsze tłumaczenia tekstów Cyryla i Nestoriusza pochodzą od autora artykułu.

${ }^{9}$ Por. Epistula 17, PG 77, 121A.

${ }^{10}$ Por. M. Simonetti, Cirillo di Alessandria, DPAC I 695.

11 Epistula 17, PG 77, 112A. 
człowiekiem"), zaznaczając istnienie w Chrystusie pełnej natury ludzkiej, zło-

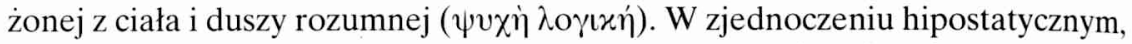
zdaniem Cyryla, natura ludzka i natura Boska pozostają całkowite, nieuszczuplone i niezmieszane. Do tego stwierdzenia, Cyryl wielokrotnie powraca, akcentując istnienie w Chrystusie pełni obu natur. Zdecydowanie odżegnuje się od sformułowań uszczuplających pełnię lub zmianę jednej z natur. W Liście do Nestoriusza, deklaruje swoje stanowisko w słowach:

„Nie mówimy bowiem, że przekształcona natura Słowa stała się ciałem ani też nie twierdzimy, że natura Słowa zamieniła się w całego człowieka, złożonego z duszy i ciała” ${ }^{12}$. ,Z konieczności jednak należy odróżnić (w Chrystusie) człowieka, który imieniem Syna został w sposób specyficzny uhonorowany, oraz Słowo Boże, któremu nazwa Syna przysługuje $z$ natury oraz istoty rzeczy" ${ }^{13}$.

Nestoriusz, nawiązując do tych stwierdzeń Cyryla, wskazuje na zgodność obu stanowisk, w tym zakresie. W swym Liście, skierowanym do Cyryla, stwierdza:

„Za co Cię chwalę, iż uznajesz rozróżnienie natur ze względu na bóstwo i człowieczeństwo oraz ich połączenie w jednej osobie; za to, że głosisz, iż Słowo Boże nie potrzebowało drugiego narodzenia $z$ niewiasty, że jasno oznajmiasz, iż Bóstwo nie mogło cierpieć. To bowiem rzeczywiście jest prawowierne i jak najbardziej przeciwne błędnym opiniom wszystkich heretyków o naturach Pana"14.

Wyżej, deklarowana zgodność, była tylko częściowa. Nestoriusz akcentując odrębność obu natur po wcieleniu, rozumiał odrębność jako separację obu natur. W ten sposób, chociaż formalnie deklarował, iż uznaje jedną osobę Chrystusa, to w istocie rzeczy mówił o dwu odrębnych podmiotach w Chrystusie, czyli o dwóch osobach. „Ciało Syna było świątynią dla Jego bóstwa”15. W konsekwencji orzekanie cech świątyni (czyli ciała) o Bóstwie w nim mieszkającym, byłoby niedorzecznością. Nestoriusz przyznaje, iż przez wcielenie natura Boska przywłaszczyła sobie cechy natury ludzkiej:

„Tak dalece zaś było [ciało] złączone z Bóstwem jakimś przedziwnym węzłem, iż mówimy, że Boska natura te cechy sobie przywłaszczyła, które skądinąd właściwe są tylko ciału. Jednak, w oparciu o to przywłaszczenie, przypisywać Słowu Bożemu narodzenie, cierpienie, śmierć i inne właściwości ciała, to wiesz, mój bracie, jest mylne na miarę błędów pogańskich lub też szaleńczych niedorzeczności Apolinarego, Ariusza czy innych heretyków albo gorsze jeszcze od jakiejś choroby czy zarazy. Oni to w konsekwencji czynią Słowo Boże niegodnym anielskiej pomocy twierdząc, że było Ono karmione piersią, podlegało procesowi wzrostu, okazywało niegdyś lęk przed śmiercią. Przemilczę obrzezanie, ofiarowanie, pocenie, głód

\footnotetext{
12 Epistula 4, PG 77, 45 B.

13 Tamże, 48C.

${ }^{14}$ Epistula 5, 6, PG 77, 52 C-D.

15 Tamże, PG 77, 56A.
} 
i pragnienie, którym podlegało ciało Chrystusa. Z naszej to przyczyny stało się. Gdyby jednak ktoś chciał te właściwości Bóstwu przypisać, popełniłby poważny błąd i stałby się w naszych oczach oszczercą godnym potępienia"16.

Akcentując zbytnio odrębność obu natur Chrystusa, Nestoriusz przyjmuje swoistego rodzaju dualizm osób. Jego zdaniem cechy natury Boskiej Chrystusa, nie mogą być przypisywane jego naturze ludzkiej. Swoje poglądy na ten temat formułuje następująco:

„Gdziekolwiek więc Boskie pisma czynią wzmiankę o władczej Opatrzności, tam zawsze narodzenie i śmierć przypisują nie Boskiej, lecz ludzkiej naturze Chrystusa. $\mathrm{Z}$ tej racji, najściślej rzecz biorąc, Święta Dziewica winna być nazywana Matką Chrystusa, a nie Matką Boga"17.

4. Jedność i nierozdzielność obu natur w Chrystusie. Cyryl odrzucając nestoriański dualizm, formułuje prawdę o jedności Chrystusa, którą można zobrazować przez analogię do jedności człowieka, złożonego z duszy i ciała. Te dwa elementy są nierozdzielnie złączone w jednym, jedynym, a nie podwójnym człowieku. Podobnie „Chrystus jest jeden i jedyny a nie podwójny”" $\mathrm{Z}$ tej też racji niemożliwe jest rozdzielenie dwóch hipostaz, po wcieleniu. Zasadę tę ujmuje Cyryl w formie anatematyzmu:

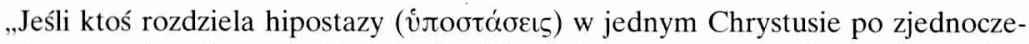
niu, łącząc je tylko związkiem godności, władzy, czy powagi, ale nie złączeniem

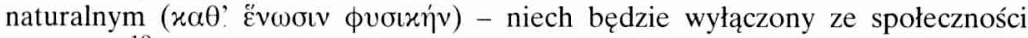
wiernych"19.

Z tej samej racji, nie wolno rozdzielać właściwości, które Pismo Święte przypisuje Chrystusowi, jakkolwiek jedne z nich, zdają się być mu przyznawane jako człowiekowi, inne zaś jako Bogu (Logosowi). Zasadę tę ujmuje Cyryl również w formę anatematyzmu:

„Jeśli ktoś nazwy Chrystusa, znajdujące się w Ewangeliach i w pismach apostolskich - podane przez świętych (pisarzy) lub przez samego Chrystusa mówiącego

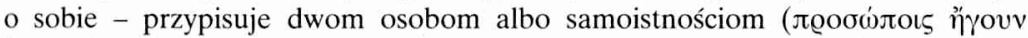

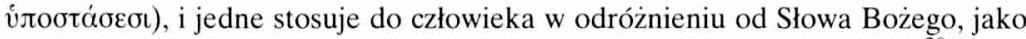
jedynie godne Boga - niech będzie wyłączony ze społeczności wiernych"20.

\footnotetext{
16 Tamże, PG 77, 56A-B.

17 Tamże, PG 77, 53B.

${ }^{18}$ Epistula 17, PG 77, 115A.

19 Tamże Anatematyzm 3, PG 77, 120C, thum. S. C. Napiórkowski, w: Maryja w tajemnicy Chrystusa, dz. cyt., s. 234.

20 Tamże Anatematyzm 4, PG 77, 120C-D.
} 
„Zatem tylko do jednej osoby odnoszone są wszystkie atrybuty i określenia, które znajdujemy w Ewangelii, do jednej osoby wcielonego Słowa Bożego ( $\mu$ í.



Z racji zjednoczenia hipostatycznego, można odnosić do Chrystusa, BogaCzłowieka, przymioty obu Jego natur. Jest to tzw. „,współorzekanie przymiotów" (communicatio idiomatum). W Liście do Nestoriusza Cyryl odrzucając jego tezy, formułuje następująco naukę ortodoksyjną:

„Dlatego też można powiedzieć, że Ten, który istniał i zrodzil się z Ojca, narodził się również według ciała z niewiasty. Nie oznacza to wcale, że Boska Jego natura wzięła początek ze Świętej Dziewicy, ani tym bardziej, że sama z siebie koniecznie potrzebowała powtórnego zrodzenia (byłoby głupio i niedorzecznie twierdzić, że Ten, który powstał przed wiekami i jest współwieczny Ojcu, potrzebuje powtórnego zrodzenia, by zacząć egzystować). Dla nas przecież, dla naszego zbawienia substancjalnie łącząc się z ludzką naturą, powstał z niewiasty, czyli zrodził się cieleśnie. Nie można powiedzieć, że najpierw narodził się zwykły człowiek ze Świętej Dziewicy, a potem dopiero Słowo w nim zamieszkało, lecz że już w łonie (Maryi) Słowo łącząc się z ciałem narodziło się niejako cieleśnie, przygotowując ciało dla swych właściwych narodzin. Mówiąc, że cierpiał i zmartwychwstał, nie twierdzimy, jakoby Boski Logos cierpiał w swej Boskiej naturze, znosząc biczowanie, przebicie gwoźdźmi i inne zranienia (bowiem bezcielesne Bóstwo nie może podlegać cierpieniom), lecz sądzimy, że cierpiał, ponieważ cierpiało ciało, które było jego własnym ciałem; a znosil te wszystkie cierpienia ze względu na nas. Ten bowiem, który nie podlega cierpieniu, obecny był w cierpiętliwym ciele.

W podobny sposób myślimy też o Jego śmierci. Słowo Boże ze swej natury jest nieśmiertelne i wieczne; daje życie i jest życiem. Ponieważ jednak Jego własne ciało, dzięki łasce Bożej, jak to mówi Paweł, za nas wszystkich skosztowało śmierci, znaczy to, że On sam za nas poddał się śmierci. Nie oznacza to wcale, że doświadczył On śmierci z tej racji, iz przynależy ona do Jego natury (tak myśleć albo mówić byłoby szaleństwem), lecz ponieważ, jak to już wcześniej powiedzieliśmy, prawdziwe Jego ciało zaznało śmierci. Podobnie ma się sprawa ze wskrzeszeniem Jego ciała, gdy mówimy o zmartwychwstaniu, nie twierdzimy, jakoby Boski Logos uległ rozpadowi, zaiste nie, lecz utrzymujemy znów, że ciało Jego zostało wskrzeszone. W ten sposób będziemy wyznawać jednego Chrystusa i Pana oddając cześć nie tyle człowiekowi i Słowu, by nie dopuszczać nawet pozoru podziału przez wprowadzenie spójnika «i», lecz Jednemu i Temu samemu. Przecież ciało nie jest czymś obcym dla Słowa; wespól z Nim zasiada wspólnie z Ojcem. Bo przecież nie dwaj synowie zasiadają razem z Ojcem, lecz jeden, dzięki zjednoczeniu, razem ze swym ciałem”22.

5. Problem terminologii. Wskazując na słabe strony doktryny Cyryla, należy w pierwszym rzędzie zwrócić uwagę na brak jednolitej terminologii

21 Epistula 17, PG 77, $121 \mathrm{~A}$.

22 Epistula 4, PG 77, 45C-48C. 
w zakresie oznaczania tak podstawowych pojęć, jak osoba i natura. Cyryl zamiennie posługuje się terminami „osoby”, bądź „natury”. W Liście 46, 2 mówi np. o „,jednej naturze Słowa

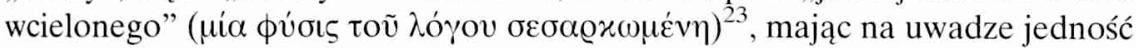

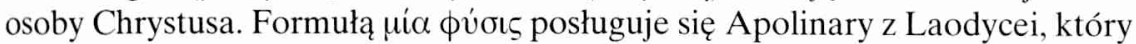
identyfikuje naturę z osobą, mówiąc o jednej tylko naturze Chrystusa: „W Chrystusie jest tylko jedna фúoıs, ponieważ jest w Nim tylko jedno źródło życia i działania, które ożywia wszystko, to jest Logos"24. Tego typu sformułowania pojawiają się, gdy Cyryl mówi o stanie po zjednoczeniu. Typową jest

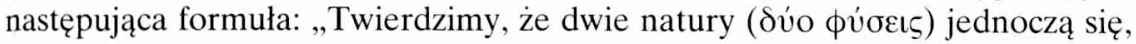
lecz po ich zjednoczeniu, nie istnieje możliwość ich rozdzielenia; zatem wie-

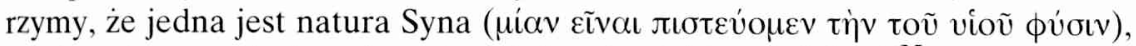
ponieważ jest on jeden, chociaż stał się człowiekiem i ciałem" 25 .

Tego rodzaju sformułowania i tym podobne pozwalają zrozumieć, dlaczego Cyryl był oskarżony o apolinaryzm i monofizytyzm. W istocie usiłuje on bronić nauki prawowiernej, odpierając dwa inne skrajne rozwiązania, to jest apolinaryzm i nestorianizm. Akcentując jedność Chrystusa, Cyryl, zdaniem niektórych teologów, stał się ojcem monofizytyzmu.

Nauka Cyryla przy uwzględnieniu korekty dotyczącej terminologii, jest nauką ortodoksyjną. Boski Logos stał się człowiekiem. Formuła Cyryla: „Słowo, jednocząc się przez unię hipostatyczną z ciałem ożywionym i duszą rozumną, stało się człowiekiem" - zostało włączone do nauczania Kościoła ${ }^{26}$.

\title{
DIE ANTINESTORIANISCHE THEOLOGIE DER MENSCHWERDUNG IN DER FASSUNG DES KYRILLS VON ALEXANDRIA
}

\author{
(Zusammenfassung)
}

In seinem Kampf gegen die nestorianischen Irrtümer verwarf Kyrill von Alexandria alle Bezeichnungen, die den inneren und wesenhaften Charakter der Vereinigung beider Naturen in der einen Person des Logos nur unzureichend präzisierten. Nestorius, der die Verschiedenheit beider Naturen nach der Menschwerdung betonte, verstand diese Verschiedenheit als Trennung beider Naturen, was im Grunde genommen zur Annahme zweier getrennter Trägersubjekte in Christus führte. Kyrill verwirft diesen nestorianischen Dualismus und formuliert die Wahrheit von

\footnotetext{
23 Por, Epistula 46,2, PG 77, $241 \mathrm{~A}$.

24 A. Grillmeier, Gesù il Cristo nella fede della Chiesa, II, Brescia 1982, s. 862.

25 Epistula 40, PG 77, 192D-193A.

${ }^{26}$ Por. KKK 466.
} 
der Einheit Christi, die durch die Analogie mit dem aus Seele und Leib zusammengesetzten Menschen veranschaulicht werden kann. Diese beiden Elemente sind in ein- und demselben, nicht doppelten Menschen untrennbar miteinander verbunden. Ähnlich ist auch Christus ein- und derselbe und nicht doppelt. Kyrill unterstreicht ganz entschieden die Einheit des Subjekts dieser Vereinigung, in dem Sinne, daß es nur eine Hypostase, d.h. eine Person des Logos gibt. Er vermeidet die Bezeichnung, Christus habe die menschliche Natur angenommen. Dagegen bedient er sich abwechselnd zweier Bezeichnungen: „Das Wort ist Fleisch geworden” und „Das Wort ist Mensch geworden". Wegen der hypostatischen Vereinigung können auf Christus, den Gott-Menschen, die Attribute seiner beiden Naturen bezogen werden. Was die Schwachstellen von Kyrills Doktrin betrifft, so muß vor allem auf das Fehlen einer einheitlichen Terminologie zur Bezeichnung so grundlegender Begriffe wie „Person” und „Natur” verwiesen werden. Bei Kyrill werden die Termini „physis” und „hypostasis” austauschbar verwendet - sei es zur Bezeichnung der Person oder der Natur. 